\title{
REVIEW
}

Open Access

\section{Pancreatic outflow tract reconstruction after pancreaticoduodenectomy: a meta- analysis of randomized controlled trials}

Xin Xin Wang ${ }^{1,2}$, Yu Ke Yan ${ }^{1}$, Bao Long Dong ${ }^{1}$, Yuan Li ${ }^{1}$ and Xiao Jun Yang ${ }^{1,3,4,5^{*}}$

\begin{abstract}
Background: To evaluate the outcomes of pancreaticogastrostomy and pancreaticojejunostomy after pancreatoduodenectomy with the help of a meta-analysis.
\end{abstract}

Methods: Randomized controlled trials comparing pancreaticogastrostomy and pancreaticojejunostomy were searched electronically using PubMed, The Cochrane Library, and EMBASE. Fixed and random-effects were used to measure pooled estimates. Research indicators included pancreatic fistula, delayed gastric emptying, postoperative hemorrhage, intraperitoneal fluid collection, wound infection, overall postoperative complications, reoperation, and mortality.

Results: Overall, 10 randomized controlled trials were included in this meta-analysis, with a total of 1629 patients. The overall incidences of pancreatic fistula and intra-abdominal collections were lower in the pancreaticogastrostomy group than in the pancreaticojejunostomy group $(\mathrm{OR}=0.73,95 \% \mathrm{Cl} 0.55 \sim 0.96, p=0.02 ; \mathrm{OR}=$ $0.59,95 \% \mathrm{Cl} 0.37 \sim 0.96, p=0.02$, respectively). The incidence of $\mathrm{B} / \mathrm{C}$ grade pancreatic fistula in the pancreaticogastrostomy group was lower than that in the pancreaticojejunostomy group, but no significant difference was observed $(\mathrm{OR}=0.61,95 \% \mathrm{Cl} 0.34 \sim 1.09, p=0.09)$. Postoperative hemorrhage was more frequent in the pancreaticogastrostomy group than in the pancreaticojejunostomy group ( $\mathrm{OR}=1.52 ; 95 \% \mathrm{Cl} 1.08 \sim 2.14, p=0.02$ ). No significant differences in terms of delayed gastric emptying, wound infection, reoperation, overall postoperative complications, mortality, exocrine function, and hospital readmission were observed between groups.

Conclusion: This meta-analysis suggests that pancreaticogastrostomy reduces the incidence of postoperative pancreatic fistula and intraperitoneal fluid collection but increases the risk of postoperative hemorrhage compared with pancreaticojejunostomy.

Keywords: Pancreaticoduodenectomy, Pancreaticogastrostomy, Pancreaticojejunostomy, Meta-analysis, Pancreatic fistula, Delayed gastric emptying

\footnotetext{
* Correspondence: yangxjmd@aliyun.com

'Department of General Surgery, Gansu Provincial Hospital, No. 204 Donggang West Road, Lanzhou 730000, Gansu Province, China

${ }^{3}$ Peoples Clinical Medicine College, Lanzhou University, Lanzhou 730000, Gansu Province, China

Full list of author information is available at the end of the article
}

(c) The Author(s). 2021 Open Access This article is licensed under a Creative Commons Attribution 4.0 International License, which permits use, sharing, adaptation, distribution and reproduction in any medium or format, as long as you give appropriate credit to the original author(s) and the source, provide a link to the Creative Commons licence, and indicate if changes were made. The images or other third party material in this article are included in the article's Creative Commons licence, unless indicated otherwise in a credit line to the material. If material is not included in the article's Creative Commons licence and your intended use is not permitted by statutory regulation or exceeds the permitted use, you will need to obtain permission directly from the copyright holder. To view a copy of this licence, visit http://creativecommons.org/licenses/by/4.0/ The Creative Commons Public Domain Dedication waiver (http://creativecommons.org/publicdomain/zero/1.0/) applies to the data made available in this article, unless otherwise stated in a credit line to the data. 


\section{Background}

Pancreaticoduodenectomy (PD) (Table 1) is widely performed as the standard procedure for malignant and benign diseases of the pancreas and periampullary region. Given the improvements in surgical techniques and postoperative care, the perioperative mortality rate for PD has dropped to below 5\% [1, 2]. However, the incidence of postoperative complications after PD is still as high as $30-50 \%$ [3] and mainly includes pancreatic fistula, delayed gastric emptying, and postoperative hemorrhage [4]. Postoperative pancreatic fistula is the most serious complication after PD, resulting in more hospital stages and charges, and directly affects patient prognosis [5]. To effectively reduce the incidence of postoperative pancreatic fistulas, methods of pancreatic outflow tract reconstruction are always the focus of exploration after PD. Pancreaticogastrostomy (PG) and pancreaticojejunostomy (PJ) are the two most common reconstruction methods after PD. A number of studies have reported the outcomes of these two reconstruction techniques to date, but the conclusions are inconsistent [6-9]. Further, previous systematic reviews and metaanalyses provide no adequate evidence to prove whether one of these methods is better than the other after PD. Given the recent increase in the number of publications of high-quality randomized controlled trials (RCTs) comparing the outcomes of PG and PJ, it is necessary to combine data from these RCTs for a new meta-analyses. Thus, in this study, we evaluate about approximately eight outcomes of PG and PJ after PD with the help of a meta-analysis of these RCTs.

\section{Methods}

\section{Inclusion and exclusion criteria}

The studies that met the following inclusion criteria were included in this meta-analysis: (1) the RCT compared PJ and PG anastomosis for pancreaticodigestive reconstruction after PD, (2) PD was performed in adult patients, and (3) Raw data was available for extraction. Further, the following studies were excluded: (1) studies that failed to meet any of the aforementioned points, (2)

Table 1 List of abbreviations

\begin{tabular}{ll}
\hline Full name & Abbreviations \\
\hline Pancreaticoduodenectomy & PD \\
Pancreaticogastrostomy & PG \\
Pancreaticojejunostomy & PJ \\
Randomized controlled trials & RCTs \\
International Study Group on Pancreatic Fistula & ISGPF \\
Odds ratio & OR \\
Confidence interval & Cl \\
Postoperative pancreatic fistula & POPF \\
\hline
\end{tabular}

studies without data for retrieval, and (3) studies that did not report any postoperative complications related to our outcome.

\section{Outcome definitions}

The primary outcome of this study was the incidence rate of pancreatic fistula. Most studies followed the International Study Group on Pancreatic Fistula (ISGPF) criteria for determining the rate ${ }^{21}$; however, some studies used other definitions (Table 2). With regard to secondary outcomes, delayed gastric emptying was defined as the inability to return to a standard diet by the end of the first postoperative week or the need for nasogastric tube decompression for 10 days or more. Hemorrhage was characterized by intra-abdominal or digestive tract bleeding. Intraperitoneal fluid collection was defined as fluid collection with or without abscess. Overall postoperative complications were defined as the overall proportion of variety of complications observed in patients. Exocrine function was compared and evaluated through postoperative steatorrhea. Wound infection was defined as purulent and infected lesions at the surgical incision site. Reoperation rate was defined as percentage of postoperative complications that was resolved by surgical treatment. Mortality was defined as death during hospitalization or within 60 days after operation.

\section{Search strategy and data collection}

This meta-analysis had been registered on PROSPERO, and the trial protocol number is CRD42021255642 (https://www.crd.york.ac.uk/prospero/). Full-text articles published between January 1995 and November 2019 were searched in PubMed, The Cochrane Library, and EMBASE. No limitations in terms of language of publication were applied. The following medical key words were used while searching: pancreaticoduodenectomy, pancreaticogastrostomy, and pancreaticojejunostomy. Besides, the references mentioned in the selected articles were also reviewed. Study selection and data extraction were performed by two reviewer independently based on the inclusion and exclusion criteria. Study reports included date on number of patients in each group, gender, mean age, definition of pancreatic fistula, reoperation, overall postoperative complications, mortality, exocrine function, and hospital readmission. Disagreements between reviewers were resolved by a discussion. The risk of bias graph and summary was used to analyze the quality of all RCTs.

\section{Statistical analyses}

Meta-analysis was performed using the Cochrane Collaboration software (RevMan version 5.3). The Cochran $\mathrm{Q}$ test was performed, with a predefined significance threshold of 0.1, to estimate the presence of 
Table 2 The characteristics of 10 RCTs

\begin{tabular}{|c|c|c|c|c|c|c|c|c|c|}
\hline ID & Years & Country & Study type & $\begin{array}{l}\text { Cases } \\
\mathrm{PG} / \mathrm{PJ}\end{array}$ & $\begin{array}{l}\text { Mean } \\
\text { age } \\
\text { (years) } \\
\text { PG/PJ }\end{array}$ & $\begin{array}{l}\text { Female\% } \\
\text { PG/PJ }\end{array}$ & $\begin{array}{l}\text { Operating } \\
\text { time (h) } \\
\text { PG/PJ }\end{array}$ & $\begin{array}{l}\text { Hospital } \\
\text { stay } \\
\text { (days) } \\
\text { PG/PJ }\end{array}$ & Definition of PF \\
\hline Yeo et al. & 1995 & $\begin{array}{l}\text { United } \\
\text { States }\end{array}$ & $\begin{array}{l}\text { Controlled } \\
\text { randomized, } \\
\text { single-center } \\
\text { trial }\end{array}$ & $73 / 72$ & $62 / 62$ & $40 / 34$ & $7.4 / 7.2$ & $17.1 / 17.7$ & $\begin{array}{l}\text { Radiographically documented leak or }>50 \\
\mathrm{~mL} \text { drainage of amylase-rich fluid on or } \\
\text { after postoperative day } 10 \text {. }\end{array}$ \\
\hline $\begin{array}{l}\text { Duffas } \\
\text { et al. }\end{array}$ & 2005 & France & $\begin{array}{l}\text { Single-blind, } \\
\text { controlled } \\
\text { randomized, } \\
\text { multicenter trial }\end{array}$ & $81 / 68$ & $58 / 59$ & $30 / 33$ & $6.5 / 6.4$ & 20.0/21.0 & $\begin{array}{l}\text { Fluid obtained through drains or } \\
\text { percutaneous aspiration, containing at least } \\
4 \text { times normal serum values of amylase for } \\
3 \text { days, confirmed by fistulography, by } \\
\text { upper gastrointestinal hydrosoluble contrast } \\
\text { or enhanced Ct scan. }\end{array}$ \\
\hline Bassi et al. & 2005 & Italy & $\begin{array}{l}\text { Controlled } \\
\text { randomized, } \\
\text { single-center } \\
\text { trial }\end{array}$ & $69 / 82$ & $59 / 56$ & $25 / 31$ & $5.6 / 5.9$ & $14.2 / 15.4$ & $\begin{array}{l}\text { Any clinical significant output of fluid, rich } \\
\text { in amylase, confirmed by fistulography. }\end{array}$ \\
\hline $\begin{array}{l}\text { Fernandez- } \\
\text { Cruz et al. }\end{array}$ & 2008 & Spain & $\begin{array}{l}\text { Controlled } \\
\text { randomized, } \\
\text { single-center } \\
\text { trial }\end{array}$ & $53 / 55$ & $63 / 63$ & $24 / 17$ & $5.0 / 5.2$ & $12.0 / 16.0$ & ISGPF definition \\
\hline $\begin{array}{l}\text { Wellner UF } \\
\text { et al. }\end{array}$ & 2012 & Germany & $\begin{array}{l}\text { Controlled } \\
\text { randomized, } \\
\text { single-center } \\
\text { trial }\end{array}$ & $59 / 57$ & $67 / 64$ & $32 / 28$ & $6.7 / 7.4$ & 15.0/17.0 & ISGPF definition \\
\hline Topal et al. & 2013 & Belgium & $\begin{array}{l}\text { Single blind, } \\
\text { controlled } \\
\text { randomized, } \\
\text { multicenter trial }\end{array}$ & $\begin{array}{l}162 / \\
167\end{array}$ & $67 / 66$ & $76 / 62$ & $4.2 / 4.2$ & 19.0/17.0 & ISGPF definition \\
\hline $\begin{array}{l}\text { Figueras } \\
\text { et al }\end{array}$ & 2013 & Spain & $\begin{array}{l}\text { Single blind, } \\
\text { controlled } \\
\text { randomized, } \\
\text { single-center } \\
\text { trial }\end{array}$ & $65 / 58$ & $67 / 66$ & $21 / 21$ & $5.5 / 5.1$ & $12.0 / 15.5$ & ISGPF definition \\
\hline $\begin{array}{l}\text { Grendar } \\
\text { et al. }\end{array}$ & 2014 & Canada & $\begin{array}{l}\text { Double blind, } \\
\text { controlled } \\
\text { randomized, } \\
\text { single-center } \\
\text { trial }\end{array}$ & $48 / 50$ & $64 / 68$ & $28 / 21$ & $5.8 / 5.9$ & $17.4 / 14.0$ & $\begin{array}{l}\text { Radiologically proven anastomotic leak or } \\
\text { continued drainage (via drain, } \\
\text { enterocutaneous fistula or wound) of lipase- } \\
\text { rich fluid on postoperative day } 10 \text {. }\end{array}$ \\
\hline $\begin{array}{l}\text { El Nakeeb } \\
\text { et al. }\end{array}$ & 2014 & Egypt & $\begin{array}{l}\text { Single-blind, } \\
\text { controlled } \\
\text { randomized, } \\
\text { single-center } \\
\text { trial }\end{array}$ & $45 / 45$ & $58 / 54$ & $22 / 18$ & $5.0 / 5.3$ & $9.0 / 8.0$ & ISGPF definition \\
\hline Keck et al. & 2016 & Germany & $\begin{array}{l}\text { Single-blind, } \\
\text { controlled } \\
\text { randomized, } \\
\text { multicenter trial }\end{array}$ & $\begin{array}{l}171 / \\
149\end{array}$ & $68 / 66$ & $67 / 56$ & $5.5 / 5.6$ & $15.0 / 16.0$ & ISGPF definition \\
\hline
\end{tabular}

heterogeneity between studies. If no significant heterogeneity $(P \geq 0.1)$ was observed, a fixed-effects model was used; otherwise, the heterogeneity and other reasons were further investigated or the random-effects model was used. The odds ratio (OR) with 95\% confidence interval (CI) was calculated for dichotomous variables. Mean differences (MDs) were calculated for continuous variables. $P<0.05$ was considered statistically significant.

\section{Results}

In all, 10 randomized controlled trials published as fulltext articles were included in the study based on the inclusion and exclusion criteria. These studies included 826 patients who underwent PG and 803 who underwent PJ after PD. We excluded 3 patients (2 from the PG group, 1 from the PJ group) from the total number of patients with perioperative in-house mortality (similar to the exclusion by Keck $\mathrm{T}$ et al. [10]), because of 
missing data. The specific patient selection process is shown in Fig. 1. The characteristics of the 10 included RCTs are shown in Table 1. The qualities of these 10 trials are shown in Fig. 2.

\section{Results of meta-analysis}

\section{Pancreatic fistula}

Ten studies (including 1629 patients) reported postoperative pancreatic fistula (POPF) rates [10-19]. The pancreatic fistula rate was $16.8 \%(139 / 826)$ in the PG group and $21.8 \%(175 / 803)$ in the PJ group. Meta-analysis showed that the rate of occurrence of pancreatic fistula was significantly lower in the PG group than in the PJ group (OR $=0.73$; 95\% CI, 0.55 0.96; $p=0.02$ ) (Fig. 3). Further, seven studies (including 1184 patients) reported pancreatic fistula (grade $\mathrm{B} / \mathrm{C}$ ) rates $[10,13-18]$. The meta-analysis showed no significant difference in the incidence of pancreatic fistula (grade $\mathrm{B} / \mathrm{C}$ ) between the PG and PJ groups $(\mathrm{OR}=0.61 ; 95 \% \mathrm{CI}, 0.34-1.09 ; p=0.09)$ (Fig. 3), but there was considerable statistical heterogeneity $\left(I^{2}=61 \%\right)$ (Fig. 3). As heterogeneity existed among these studies $(p<0.1)$, a random-effects model was used to minimize the analytical error.

\section{Delayed gastric emptying}

Eight studies including 1382 patients reported delayed gastric emptying $[10,11,13-15,17-19]$. The incidence rates of delayed gastric emptying in the PG and PJ groups were 21.7\% (151/697) and 20.0\% (137/ 685), respectively. The meta-analysis showed no

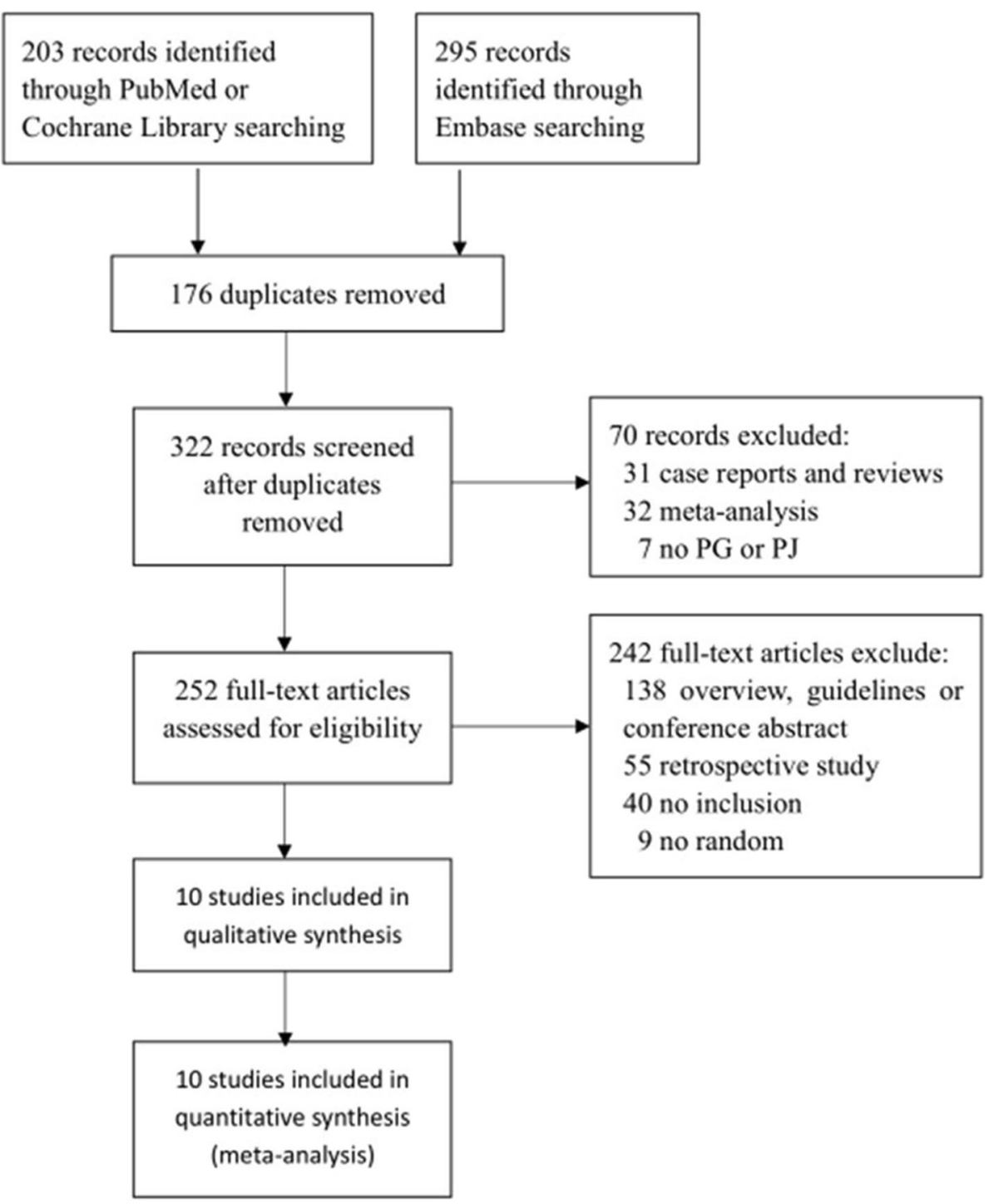

Fig. 1 Study flow diagram 

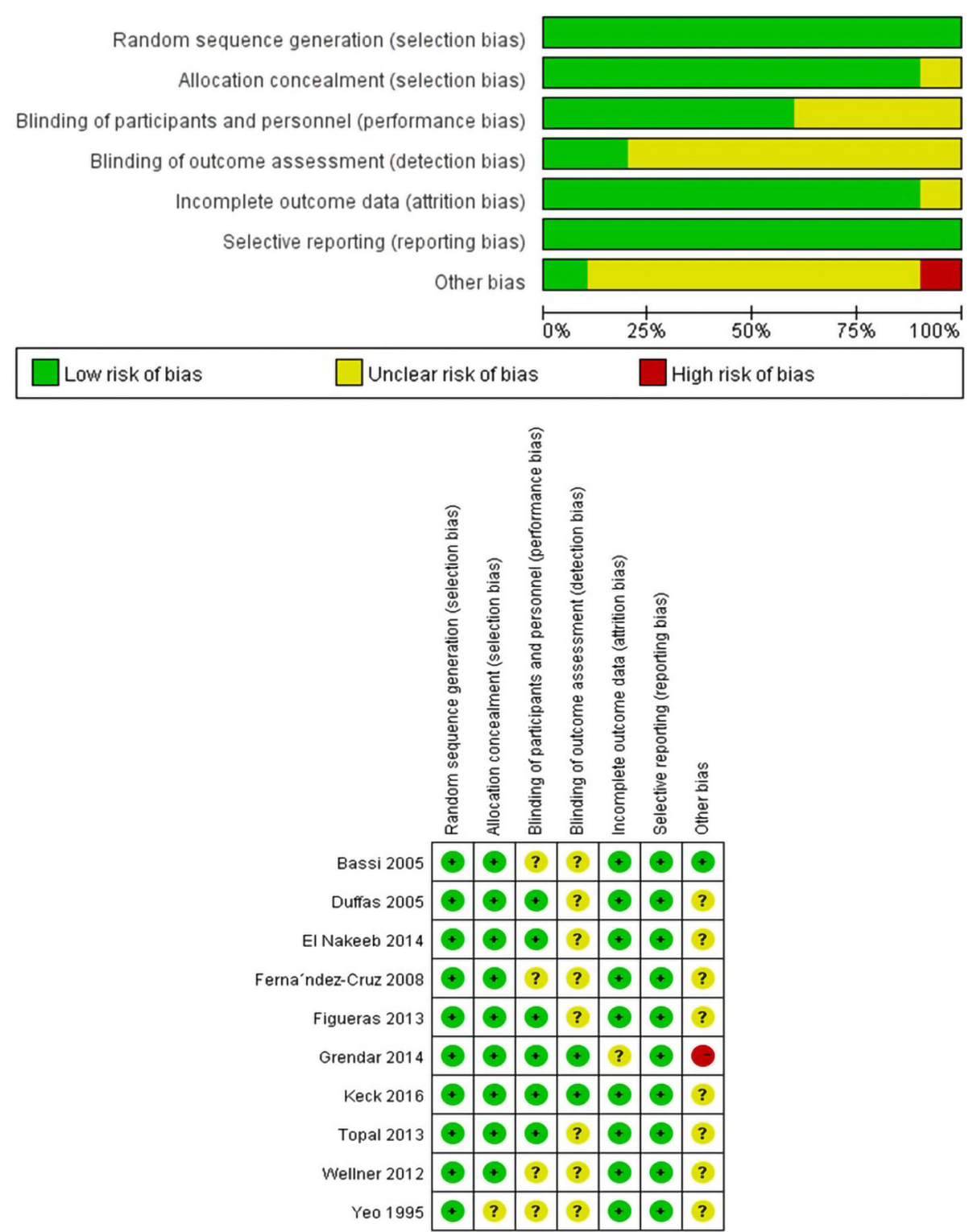

Fig. 2 The quality of these 10 trials. The risk of bias graph and summary

significant difference in delayed gastric emptying between the PG and PJ groups (OR=1.06; 95\% CI, 0.671.69; $p=0.79$ ) (Fig. 3). However, there was considerable statistical heterogeneity $\left(I^{2}=54 \%\right)$ (Fig. 3$)$. As heterogeneity existed among these studies $(p<0.1)$, a random-effects model was used to minimize the analytical error.

\section{Postoperative hemorrhage}

Eight studies including 1386 patients reported postoperative hemorrhage as a complication $[10-15,17,18]$. The incidence rates of postoperative hemorrhage in the PG and PJ groups was 13.8\% (97/705) and 9.25\%
(63/681), respectively. The meta-analysis showed that the incidence rate of hemorrhage was significantly lower in the PJ group than in the PG group (OR= 1.52; 95\% CI, 1.08-2.14; $p=0.02$ ) (Fig. 4). Further, three studies reported the incidence of postoperative hemorrhage (grade $\mathrm{B} / \mathrm{C}$ ) $[10,15,18]$ and the combined analysis of these studies showed no significant difference between PG and PJ groups ( $\mathrm{OR}=1.56$; $95 \%$ CI, 0.90-2.67; $p=0.11$ ) (Fig. 4).

\section{Intraperitoneal fluid collection}

Eight studies including 1441 patients reported results on intraperitoneal fluid collection $[10-12,14,15,17-$ 


\begin{tabular}{|c|c|c|c|c|c|c|c|c|c|c|}
\hline Study or Subgroup & $\begin{array}{r}P G \\
\text { Events }\end{array}$ & Total & $\begin{array}{r}\text { PJ } \\
\text { Events }\end{array}$ & Total & Weight & $\begin{array}{c}\text { Odds Ratio } \\
\text { M-H. Random. } 95 \% \mathrm{Cl}\end{array}$ & & $\begin{array}{r}\text { Odds } \\
M-H \text { Rand }\end{array}$ & $\begin{array}{l}\text { S Ratio } \\
\text { dom. } 95 \% \mathrm{Cl}\end{array}$ & \\
\hline Bassi 2005 & 9 & 69 & 13 & 82 & $8.2 \%$ & $0.80[0.32,1.99]$ & & $*$ & & \\
\hline Duffas 2005 & 13 & 81 & 14 & 68 & $9.7 \%$ & $0.74[0.32,1.70]$ & & & & \\
\hline EI Nakeeb 2014 & 10 & 45 & 9 & 45 & $6.8 \%$ & $1.14[0.41,3.15]$ & & & & \\
\hline Ferna'ndez-Cruz 2008 & 3 & 53 & 10 & 55 & $3.9 \%$ & $0.27[0.07,1.04]$ & & & & \\
\hline Figueras 2013 & 10 & 65 & 20 & 58 & $9.1 \%$ & $0.35[0.15,0.82]$ & & 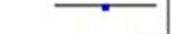 & & \\
\hline Grendar 2014 & 12 & 48 & 9 & 50 & $7.3 \%$ & $1.52[0.57,4.02]$ & & 1 & & \\
\hline Keck 2016 & 34 & 171 & 33 & 149 & $20.3 \%$ & $0.87[0.51,1.50]$ & & $\rightarrow$ & & \\
\hline Topal 2013 & 33 & 162 & 52 & 167 & $22.6 \%$ & $0.57[0.34,0.94]$ & & - & & \\
\hline Wellner 2012 & 6 & 59 & 7 & 57 & $5.3 \%$ & $0.81[0.25,2.57]$ & & & & \\
\hline Yeo 1995 & 9 & 73 & 8 & 72 & $6.8 \%$ & $1.13[0.41,3.10]$ & & & & \\
\hline Total $(95 \% \mathrm{Cl})$ & & 826 & & 803 & $100.0 \%$ & $0.73[0.55,0.96]$ & & & & \\
\hline Total events & 139 & & 175 & & & & & & & \\
\hline $\begin{array}{l}\text { Heterogeneity: } \operatorname{Tau}^{2}=0 \\
\text { Test for overall effect: } Z\end{array}$ & $\begin{array}{l}2 ; \mathrm{Chi}^{2}= \\
2.26(\mathrm{P}=\end{array}$ & $\begin{array}{l}10.05, c \\
0.02)\end{array}$ & $d f=9(P=$ & $=0.35)$ & $I^{2}=10 \%$ & & 0.01 & $\begin{array}{ll}0.1 & 1 \\
\text { Favours [PG] }\end{array}$ & $1 \quad 10$ & 100 \\
\hline
\end{tabular}

A

\begin{tabular}{|c|c|c|c|c|c|c|c|c|c|c|}
\hline Study or Subgroup & $\begin{array}{r}P G \\
\text { Events }\end{array}$ & Total & $\begin{array}{r}\text { PJ } \\
\text { Events }\end{array}$ & Total & Weight & $\begin{array}{l}\text { Odds Ratio } \\
\mathrm{M} \cdot \mathrm{H}, \text { Random, } 95 \% \mathrm{cl}\end{array}$ & & $\begin{array}{r}\text { Odds } \\
M-H_{1} \text { Rando }\end{array}$ & $\begin{array}{l}\text { Ratio } \\
\text { lom. } 95 \% \mathrm{Cl}\end{array}$ & \\
\hline EI Nakeeb 2014 & 7 & 45 & 4 & 45 & $11.1 \%$ & $1.89[0.51,6.97]$ & & & & \\
\hline Ferna'ndez-Cruz 2008 & 2 & 53 & 10 & 55 & $8.9 \%$ & $0.18[0.04,0.85]$ & & & & \\
\hline Figueras 2013 & 7 & 65 & 19 & 58 & $15.0 \%$ & $0.25[0.10,0.65]$ & & & & \\
\hline Grendar 2014 & 8 & 48 & 6 & 50 & $12.8 \%$ & $1.47[0.47,4.59]$ & & & & \\
\hline Keck 2016 & 34 & 171 & 33 & 149 & $20.8 \%$ & $0.87[0.51,1.50]$ & & & & \\
\hline Topal 2013 & 13 & 162 & 33 & 167 & $18.8 \%$ & $0.35[0.18,0.70]$ & & & & \\
\hline Wellner 2012 & 6 & 59 & 7 & 57 & $12.6 \%$ & $0.81[0.25,2.57]$ & & & & \\
\hline Total $(95 \% \mathrm{Cl})$ & & 603 & & 581 & $100.0 \%$ & $0.61[0.34,1.09]$ & & & & \\
\hline Total events & 77 & & 112 & & & & & & & \\
\hline $\begin{array}{l}\text { Heterogeneity: } \mathrm{Tau}^{2}=0 . \\
\text { Test for overall effect: } Z\end{array}$ & $\begin{array}{l}4 ; \mathrm{Chi}^{2}= \\
1.67(\mathrm{P}=\end{array}$ & $\begin{array}{l}15.33, \\
0.09)\end{array}$ & $d f=6(P=$ & $=0.02)$; & $; 1^{2}=61 \%$ & & 0.01 & $\begin{array}{l}0.1 \\
\text { Favours }[P G]\end{array}$ & $\begin{array}{l}10 \\
\text { Favours [PJ] }\end{array}$ & 100 \\
\hline
\end{tabular}

B

\begin{tabular}{|c|c|c|c|c|c|c|c|c|c|c|}
\hline Study or Subgroup & $\begin{array}{r}P G \\
\text { Events }\end{array}$ & Total & $\begin{array}{r}\text { PJ } \\
\text { Events }\end{array}$ & Total & Weight & $\begin{array}{l}\text { Odds Ratio } \\
\text { M-H, Random, } 95 \% \mathrm{Cl}\end{array}$ & & $\begin{aligned} \text { Odds } \\
\mathrm{M}-\mathrm{H}, \text { Rando }\end{aligned}$ & $\begin{array}{l}\text { Ratio } \\
\text { lom. } 95 \% \mathrm{Cl}\end{array}$ & \\
\hline Bassi 2005 & 2 & 69 & 10 & 82 & $6.6 \%$ & $0.21[0.05,1.02]$ & & & & \\
\hline EI Nakeeb 2014 & 9 & 45 & 4 & 45 & $8.8 \%$ & $2.56[0.73,9.03]$ & & & & \\
\hline Ferna'ndez-Cruz 2008 & 2 & 53 & 8 & 55 & $6.3 \%$ & $0.23[0.05,1.14]$ & & & & \\
\hline Figueras 2013 & 19 & 65 & 15 & 58 & $14.6 \%$ & $1.18[0.54,2.62]$ & & & & \\
\hline Keck 2016 & 64 & 171 & 62 & 149 & $20.5 \%$ & $0.84[0.54,1.32]$ & & & & \\
\hline Topal 2013 & 25 & 162 & 13 & 167 & $15.9 \%$ & $2.16[1.06,4.39]$ & & & & \\
\hline Wellner 2012 & 14 & 59 & 9 & 57 & $12.5 \%$ & $1.66[0.65,4.21]$ & & & & \\
\hline Yeo 1995 & 16 & 73 & 16 & 72 & $14.7 \%$ & $0.98[0.45,2.15]$ & & & & \\
\hline Total $(95 \% \mathrm{Cl})$ & & 697 & & 685 & $100.0 \%$ & $1.06[0.67,1.69]$ & & & & \\
\hline Total events & 151 & & 137 & & & & & & & \\
\hline \multicolumn{7}{|c|}{$\begin{array}{l}\text { Heterogeneity: } \mathrm{Tau}^{2}=0.22 ; \mathrm{Chi}^{2}=15.38, \mathrm{df}=7(P=0.03): \mathrm{I}^{2}=54 \% \\
\text { Test for overall effect: } Z=0.26(P=0.79)\end{array}$} & 0.01 & $\begin{array}{ll}0.1 & 1 \\
\text { Favours [PG] }\end{array}$ & $\begin{array}{l}1 \\
\text { Favours [PJ] }\end{array}$ & 100 \\
\hline
\end{tabular}

C

Fig. 3 Forrest plot of meta-analysis: A postoperative pancreatic fistula, B the postoperative grade B/C pancreatic fistula, and $\mathbf{C}$ delayed gastric emptying; PD pancreaticogastrostomy; PJ pancreaticojejunostomy

19]. The rates of intraperitoneal fluid collection in the PG and PJ groups were 10.7\% (78/733) and $16.0 \%$ $(113 / 708)$, respectively. This meta-analysis showed that the rate of intraperitoneal fluid collection was significant lower in the PG group than in the PJ group (OR=0.59; 95\% CI, 0.37-0.96; $p=0.03$ ) (Fig. 4), and there was considerable statistical heterogeneity $\left(I^{2}=45 \%\right) \quad$ (Fig. 4). As heterogeneity existed among these studies $(p<0.1)$, a random-effects model was used to minimize the analytical error. 


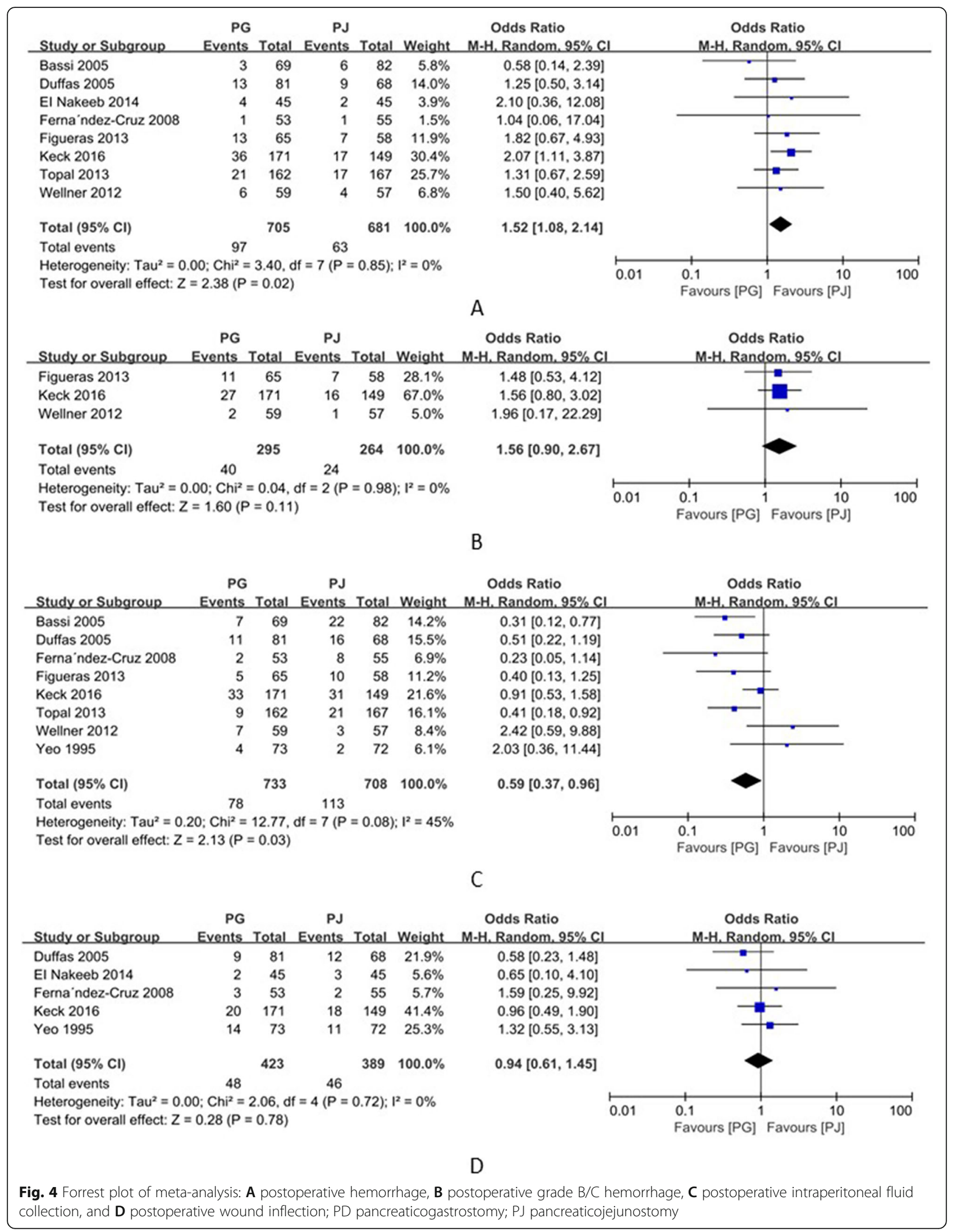




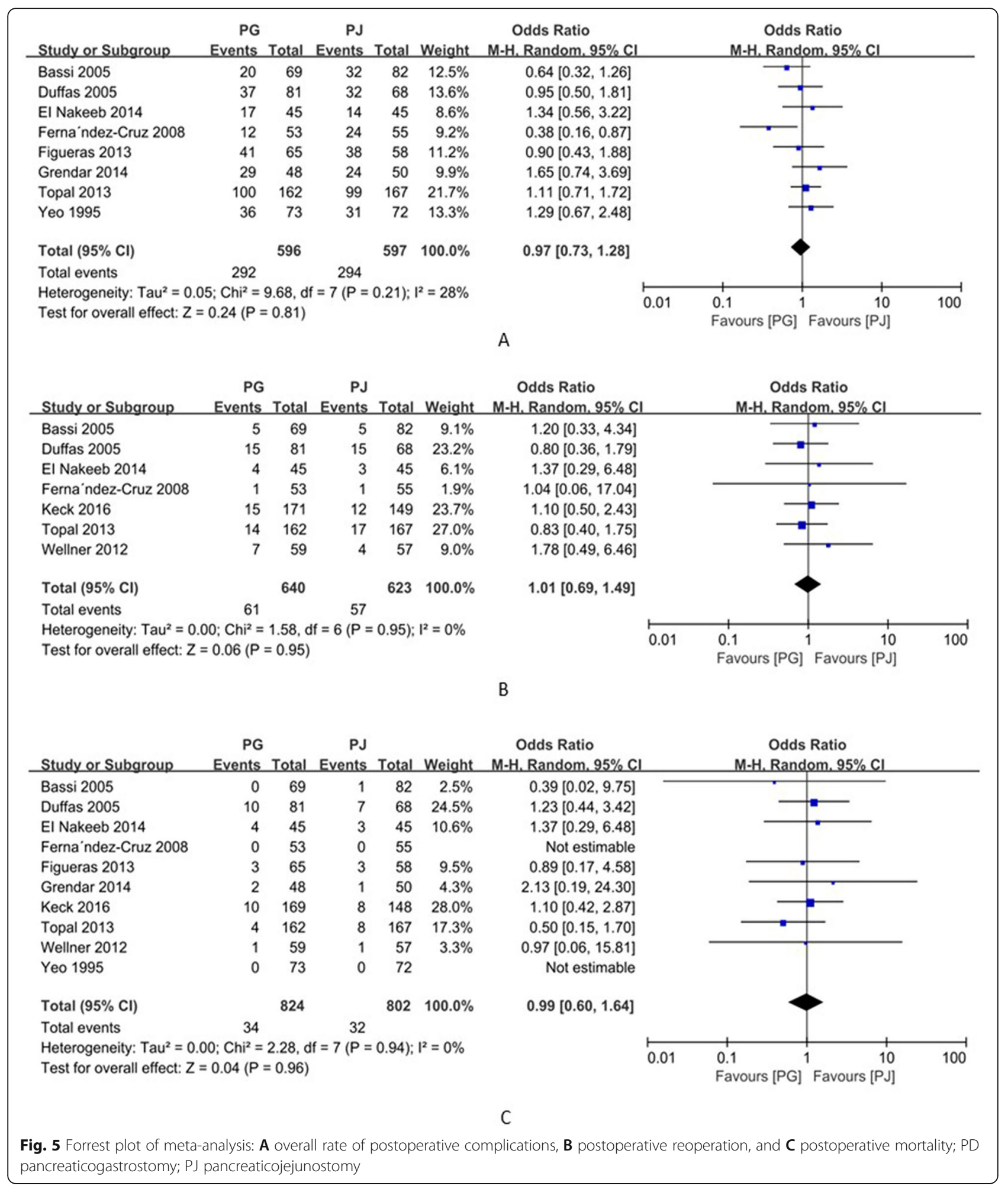

\section{Wound infection}

In all, five studies including 812 patients reported on wound infection in patients [10, 12-14, 19]. The rates of infection in the PG and PJ groups were 11.4\% (48/423) and $11.8 \%$ (46/389), respectively. Accordingly, the metaanalysis showed no significant difference in wound infection between the PG and PJ groups (OR=0.94; 95\% CI, $0.61-1.45 ; p=0.78$ ) (Fig. 4). 


\section{Overall postoperative complications}

Overall postoperative complications included intraabdominal and medical complications. Eight studies (including 1193 patients) reported the rates of overall postoperative complications in patients [11-17, 19]. The overall postoperative complications rate was $49.0 \%$ (292/ 596) in the PG group and 49.3\% (294/597) in the PJ group. Accordingly, the meta-analysis showed no significant difference in the overall postoperative complications rate between groups $(\mathrm{OR}=0.97$; $95 \% \mathrm{CI}, 0.73-1.28$; $p=0.81$ ) (Fig. 5).

\section{Reoperation rate}

Reasons for reoperation mainly included the following: continuous postoperative bleeding (grade $\mathrm{B} / \mathrm{C}$ ) not suitable for conservative treatment, pancreatic fistula (grade $\mathrm{B} / \mathrm{C}$ ) not suitable for percutaneous drainage, and anastomotic dehiscence or obstruction. Seven studies including 1263 patients reported reoperations $[10-14,17,18]$. The reoperation rates were 9.53\% (61/640) and 9.15\% (57/ 623 ) in the PG and PJ groups, respectively, with no significant difference observed between groups $(\mathrm{OR}=1.01$; 95\% CI, 0.61-1.49; $p=0.95$ ) (Fig. 5).

\section{Mortality}

Ten studies (including 1626 patients) reported on the incidence of postoperative mortality rates [10-19]. The overall mortality rates were $4.1 \%(34 / 824)$ and $4.0 \%(32 /$
802) in the PG and PJ groups, respectively, with no significant difference between groups $(\mathrm{OR}=0.99 ; 95 \% \mathrm{CI}$, $0.60-1.64 ; p=0.96$ ) (Fig. 5).

\section{Exocrine function}

Three studies compared the results of postoperative exocrine function comparison $[10,13,15]$. However, one study compared exocrine function by stool elastase [15] and two studies compared exocrine function by steatorrhea $[10,13]$. Accordingly, we compared exocrine function through postoperative steatorrhea. The postoperative steatorrhea rates were $15.96 \%(34 / 213)$ and $15.97 \%$ (31/194) in the PG and PJ groups, respectively, with no significant difference between groups $(\mathrm{OR}=1.29$; 95\% CI, 0.27-6.28; p=0.75) (Fig. 6).

\section{Hospital readmission}

Two studies reported the results of hospital readmission $[15,17]$. Hospital readmission rates were $7.5 \%$ (17/227) and $10.2 \%(23 / 225)$ in the PG and PJ groups, respectively. The hospital readmission rate is slightly lower in PG group than PJ group, but there was no significant difference between groups $(\mathrm{OR}=0.58$; 95\% CI, 0.08-4.19; $\mathrm{p}=0.59$ ) (Fig. 6).

\section{Discussion}

Pancreatic fistula is one of the most frequent complications of PD that occurs when pancreatic anastomosis

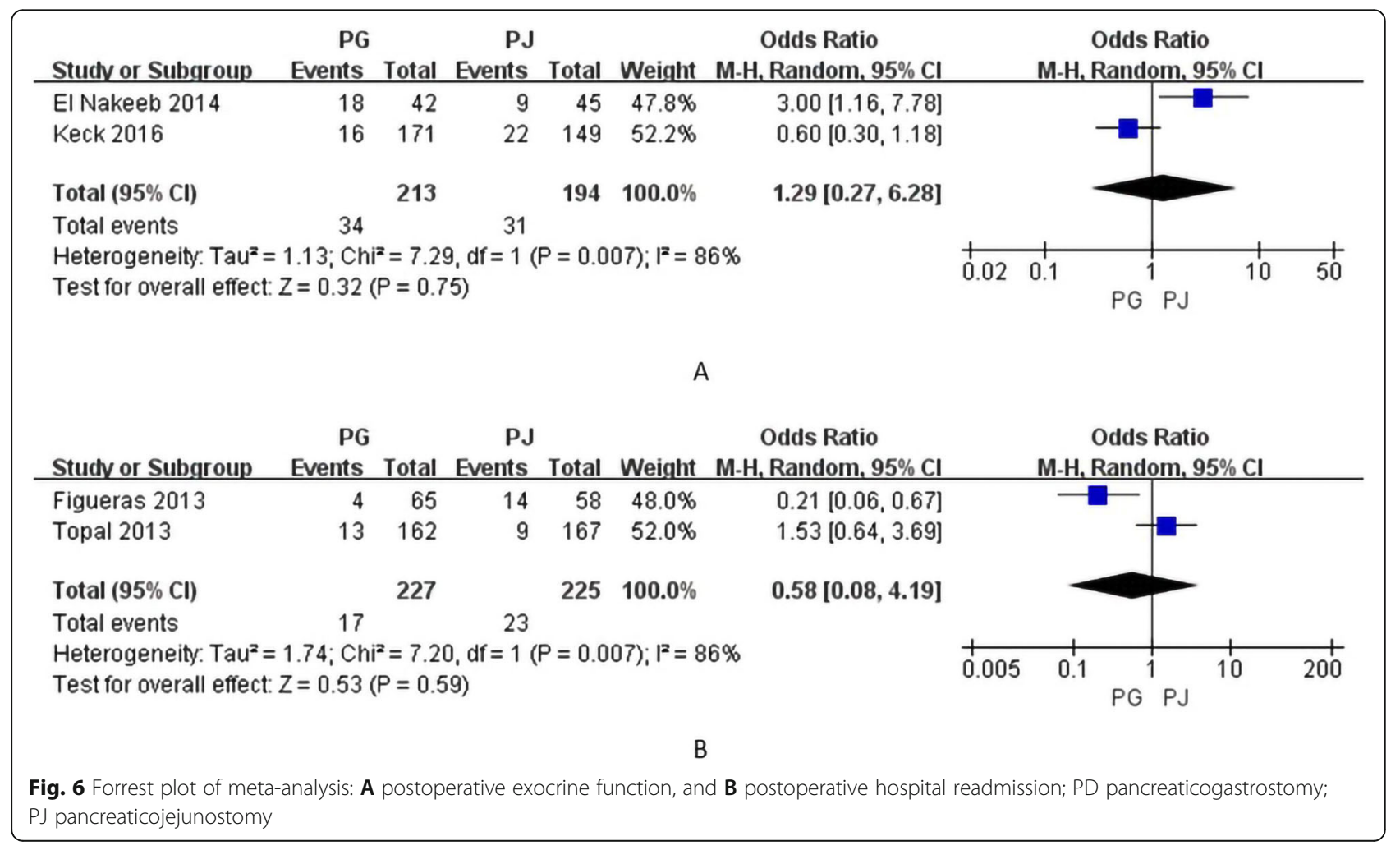


fails to heal following surgery [20]. Depending on the clinical impact, ISGPF has established the grading of pancreatic fistula (grades A, B, and C) [21] depending on the clinical impact, wherein grade $\mathrm{B} / \mathrm{C}$ pancreatic fistula is associated with a deterioration in the clinical status of patients, necessitating intensive care management, and may lead to delayed recovery, reoperation risk, and a distinct risk of mortality. Patient factors, including age, preoperative biliary drainage, body mass index, vital organ function, and frail or not, also affect the incidence of POPF [22-25], but the treatment of the pancreatic stump and the method of anastomosis are still key to prevent the occurrence of pancreatic fistula. Nevertheless, pancreatic outflow tract reconstruction after PD remains to be a challenging problem after PD to date, even for experienced surgeons, and based on published literature, no single reconstruction method is suitable for all patients. Some retrospective studies have reported that the incidence of POPF in the PG group was lower than that in the PJ group [26-28], whereas other original studies and meta-analyses show that PG does not reduce the incidence of POPF $[11,15,29,30]$. In this metaanalysis, we showed that the PG group was associated with a lower incidence of pancreatic fistula than the PJ group. However, the incidence rates of grade $\mathrm{B} / \mathrm{C}$ pancreatic fistula in the PG and PJ groups were 12.8\% (77/ $603)$ and $19.3 \%(112 / 581)$, respectively; although the difference was not statistically significant between the two groups, the incidence rate in the former was considerably lower than that in the latter group. This is consistent with the outcomes reported in a recent metaanalysis [31]. The lower incidence rate of pancreatic fistula after PG may be associated with the following factors: high blood supply to the stomach is helpful for the healing of the anastomosis, the stomach acids can inhibit trypsin activation and bacterial breeding, and the gastric wall is helpful for the fixation of residual pancreas. Moreover, a French study showed that the incidence rate of POPF in patients with a soft pancreatic texture was significantly higher than the rate in patients with a hard pancreatic texture or those with the presence of fibrosis [32], This is in line with the conclusion reported by a Japanese study reporting that a small pancreatic duct $(\leq 3 \mathrm{~mm})$ or soft pancreas have the greatest risk of developing a pancreatic fistula [33]. However, the proportion of soft textured pancreas between patients in both groups, PG and PJ, was comparable in the studies included in our meta-analysis. Therefore, PG showed superiority in reducing the incidence of pancreatic fistula, compared with PJ. Finally, heterogeneity in the occurrence of grade $\mathrm{B} / \mathrm{C}$ pancreatic fistula $\left(I^{2}=61 \%\right)$ may have resulted from of the use of different definitions among the included studies as the incidence of pancreatic fistula depends on and varies with different definitions [34].
Delayed gastric emptying is another complication after PD; it was reported by Warshaw in 1985 [35], and since then, the risk factors of delayed gastric emptying have been studied. Some previous studies have reported that low motilin levels [36-38], vagus nerve injury, pylorospasm ischemia, pancreatic fistula, and mechanical factors are associated with delayed gastric emptying. Meanwhile, the effects of different anastomosis methods on delayed gastric emptying have also been studied. Our metaanalysis showed no significant difference in delayed gastric emptying between the PG and PJ groups. This was consistent with the findings by Park et al. [39]. Moreover, Figueras et al. found that the incidence rates of grade $C$ delayed gastric emptying in the PG and PJ groups were $9 \%(6 / 65)$ and $7 \%(4 / 58)$, respectively, with no significant difference between groups [15]. However, there was considerable statistical heterogeneity in the result of delayed gastric emptying $\left(I^{2}=53 \%\right)$; this may be because the proportion of patients who underwent pylorus-preserving pancreaticoduodenectomy with gastric partition varied among the included studies and some studies showed that the incidence of delayed gastric emptying was higher in the pylorus-preserving pancreaticoduodenectomy with gastric partition group than in the PD group [40, 41].

With regard to postoperative hemorrhage, a Japanese study showed that the rate of bleeding was similar between PG and PJ groups [42]. This meta-analysis showed that the hemorrhage rate was higher in the PG group than in the PJ group, but grade $\mathrm{B} / \mathrm{C}$ hemorrhage rate was not different between PG and PJ groups; this may be one of the reasons why the rate of reoperation and mortality was not different between the two groups, because patients with grade $\mathrm{B}$ and $\mathrm{C}$ postoperative hemorrhage had significantly higher postoperative postoperative complications compared with those without postoperative hemorrhage or those with grade A postoperative hemorrhage based on the (International Study Group of Pancreatic Surgery) definition and clinical grading of hemorrhage [43]. The other possible explanation for this finding is that the alkaline pancreatic juice is emptied directly into the stomach in PG, which results in alkaline gastritis, reflux esophagitis, gastrointestinal dysfunction, and increased incidence of stress ulcer. Moreover, the pancreatogastric anastomosis is exposed to gastric secretions. These factors may lead to a high hemorrhage rate in the PG group.

Lower intra-abdominal fluid collection rate was observed in the PG group compared with the PJ group, which may be associated with the low incidence of pancreatic fistula in the PG group given that pancreatic fistulas are associated with intra-abdominal fluid collection [44]. Reoperation rate was not different between PG and PJ groups because an increasing number of cases of 
pancreatic fistulas and hemorrhages can be successfully managed by conservative treatment. No significant difference was found in the overall postoperative complications and mortality rates between the two groups. Apart from the abovementioned factors, intraoperative blood loss, postoperative care and nutritional status, use of prophylactic somatostatin and residual pancreatic secretion, and surgeon-related factors, can affect the incidence of overall postoperative complications and mortality after PD.

Three studies included in this meta-analysis evaluated endocrine and exocrine functions and found no differences in terms of endocrine function by comparing the prevalence of diabetes mellitus between PG and PJ [10, $13,15]$. This finding was consistent with the results reported by Schmidt et al. [45]. With regard to residual pancreatic exocrine function after PD, some retrospective studies have reported that patients who underwent PD with PG presented with considerably higher pancreatic exocrine insufficiency than patients who underwent PD with PJ [46, 47]. Similarly, El Nakeeb et al. found a higher incidence of steatorrhea 1 year after PG [13]. However, Figueras et al. found high levels of stool elastase 3-6 months after PG [15], suggesting better exocrine function in the PG group; this is in line with the findings reported by Keck et al. [10]. However, this is still controversial; therefore, high-quality RCTs comparing PG and PJ with a consistent biochemical index and long-term outcomes are still required to analyze the relationship between exocrine function and type of anastomosis and the factors affecting the exocrine function.

The limitations of meta-analysis include the following: the number of included studies was limited, the definition of pancreatic fistula was not unified among all published studies, and different surgical methods (PD and PPPD) were used. These factors may affect the reliability of the conclusion. In addition, the current study was not registered and may also have been biased in its smallness, but we still followed strict systematic review procedures.

\section{Conclusion}

This study shows that PG reduces the incidence of postoperative pancreatic fistula and intraperitoneal fluid collection, but does not reduce the risk of delayed gastric emptying, postoperative reoperation rate, wound infection, overall postoperative complications, exocrine function, hospital readmission, and mortality rates. Further, PG increases the incidence of postoperative bleeding. Thus, PG cannot be considered superior to PJ. At the same time, a variety of improved anastomotic methods are also gradually applied in clinical practice, which include modified invaginated PJ and modified duct-tomucosa PJ among others [48, 49]. Accordingly, further high-quality RCTs are still required for the validation of these results is necessary.

\begin{abstract}
Acknowledgements
I would like to extend my sincere gratitude to my supervisor, Xiaojun Yang, for his instructive advice and useful suggestion
\end{abstract}

\section{Copyright and plagiarism}

We declare that this manuscript is original, has not been published before, and is not currently being considered for publication elsewhere.

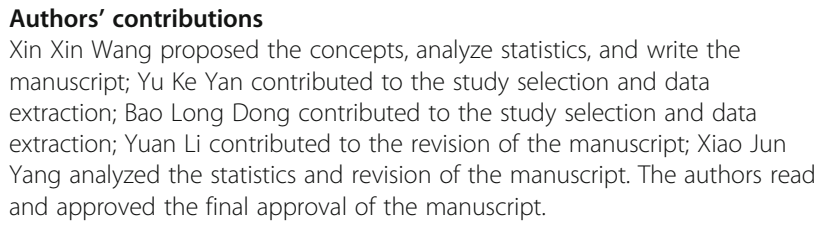

\section{Funding}

This work was supported by the National Natural Science Foundation of China, No. 81660398; Hospital Key Program of National Scientific Research Cultivation Plan, No.19SYPYA-12. And the fundings can support the publication of this manuscript.

\section{Availability of data and materials}

Full-text articles published were searched in PubMed (https://pubmed.ncbi. nlm.nih.gov/), The Cochrane Library (https://www.cochranelibrary.com), and EMBASE (https://www.embase.com), and figures have made by the Cochrane Collaboration software RevMan version 5.3. So data sharing is not applicable to this article as no datasets were generated or analyzed during the current study.

\section{Declaration}

\section{Ethics approval and consent to participate}

This manuscript is not reported studies involving human participants, human data, or human tissue. So the "ethics approval and consent to participate" is not appropriate for our manuscript.

\section{Consent for publication}

This manuscript does not contain any individual person's data in any form (including any individual details, images or videos). So the "Consent for publication" is not appropriate for our manuscript.

\section{Competing interests}

We confirm that the manuscript has been read and approved by all named authors and that there are no other persons who satisfied the criteria for authorship but are not listed. We further confirm that the order of authors listed in the manuscript has been approved by all of us. We also declare that they have no known competing financial interests or personal relationships that could have appeared to influence the work reported in this paper. We understand that the corresponding author is the sole contact for the editorial process. He is responsible for communicating with the other authors about progress, submissions of revisions, and final approval of proofs.

\section{Author details}

${ }^{1}$ Department of General Surgery, Gansu Provincial Hospital, No. 204 Donggang West Road, Lanzhou 730000, Gansu Province, China. ${ }^{2}$ The 1st Clinical Medicine College, Gansu University of Chinese Medicine, Lanzhou 730000, Gansu Province, China. ${ }^{3}$ Peoples Clinical Medicine College, Lanzhou University, Lanzhou 730000, Gansu Province, China. ${ }^{4}$ Gansu key Laboratory of Molecular Diagnostics and Precision Medicine for Surgical Oncology, Gansu Provincial Hospital, Lanzhou 730000, Gansu Province, China. ${ }^{5}$ Gansu Research Center of Prevention and Control Project for Digestive Oncology, Gansu Provincial Hospital, Lanzhou 730000, Gansu Province, China. 
Received: 17 December 2020 Accepted: 22 June 2021 Published online: 06 July 2021

\section{References}

1. Buchler MW, Wagner M, Schmied BM, UhI W, Friess H, Z'Graggen K. Changes in morbidity after pancreatic resection: toward the end of completion pancreatectomy. Arch Surg (Chicago, III : 1960). 2003;138(12): 1310-4 discussion 1315.

2. Kimura W, Miyata H, Gotoh M, Hirai I, Kenjo A, Kitagawa Y, et al. A pancreaticoduodenectomy risk model derived from 8575 cases from a national single-race population (Japanese) using a web-based data entry system: the 30-day and in-hospital mortality rates for pancreaticoduodenectomy. Annals of surgery. 2014;259(4):773-80. https:// doi.org/10.1097/SLA.0000000000000263.

3. Satoi S, Toyokawa H, Yanagimoto H, Yamamoto T, Yamao J, Kim S, et al. A new guideline to reduce postoperative morbidity after pancreaticoduodenectomy. Pancreas. 2008;37(2):128-33. https://doi.org/10.1 097/MPA.0b013e318162cb53.

4. Karim SAM, Abdulla KS, Abdulkarim QH, Rahim FH. The outcomes and complications of pancreaticoduodenectomy (Whipple procedure): cross sectional study. Int J Surgery (London, England). 2018;52:383-7.

5. Pratt WB, Maithel SK, Vanounou T, Huang ZS, Callery MP, Vollmer CM Jr. Clinical and economic validation of the International Study Group of Pancreatic Fistula (ISGPF) classification scheme. Ann Surg. 2007;245(3):44351. https://doi.org/10.1097/01.sla.0000251708.70219.d2.

6. Qin H, Luo L, Zhu Z, Huang J. Pancreaticogastrostomy has advantages over pancreaticojejunostomy on pancreatic fistula after pancreaticoduodenectomy. A meta-analysis of randomized controlled trials. International Journal of Surgery. 2016;36(Pt A):18-24. https://doi.org/10.101 6/j.ijsu.2016.10.020

7. Zhu F, Wang M, Wang X, Tian R, Shi C, Xu M, et al. Modified technique of pancreaticogastrostomy for soft pancreas with two continuous hemstitch sutures: a single-center prospective study. J Gastrointest Surg. 2013;17(7): 1306-11.

8. Kim SW, Youk EG, Park YH. Comparison of pancreatogastrostomy and pancreatojejunostomy after pancreatoduodenectomy performed by one surgeon. World Journal of Surgery. 1997;21(6):640-3. https://doi.org/10.1007/ s002689900286.

9. Lai EC, Lau SH, Lau WY. Measures to prevent pancreatic fistula after pancreatoduodenectomy: a comprehensive review. Arch Surg (Chicago, III : 1960). 2009:144(11):1074-80.

10. Keck T, Wellner UF, Bahra M, Klein F, Sick O, Niedergethmann M, et al. Pancreatogastrostomy versus pancreatojejunostomy for reconstruction after PANCreatoduodenectomy (RECOPANC, DRKS 00000767): perioperative and long-term results of a multicenter randomized controlled trial. Annals of Surgery. 2016;263(3):440-9. https://doi.org/10.1097/SLA.0000000000001240.

11. Bassi C, Falconi M, Molinari E, Salvia R, Butturini G, Sartori N, et al. Reconstruction by pancreaticojejunostomy versus pancreaticogastrostomy following pancreatectomy: results of a comparative study. Ann Surg. 2005; 242(6):767-71, discussion 771-763. https://doi.org/10.1097/01.sla.00001 89124.47589.6d

12. Duffas JP, Suc B, Msika S, Fourtanier G, Muscari F, Hay JM, et al. A controlled randomized multicenter trial of pancreatogastrostomy or pancreatojejunostomy after pancreatoduodenectomy. American journal of surgery. 2005;189(6):720-9. https://doi.org/10.1016/j.amjsurg.2005.03.015.

13. El Nakeeb A, Hamdy E, Sultan AM, Salah T, Askr W, Ezzat H, et al. Isolated Roux loop pancreaticojejunostomy versus pancreaticogastrostomy after pancreaticoduodenectomy: a prospective randomized study. HPB. 2014; 16(8):713-22.

14. Fernandez-Cruz L, Cosa R, Blanco L, Lopez-Boado MA, Astudillo E. Pancreatogastrostomy with gastric partition after pylorus-preserving pancreatoduodenectomy versus conventional pancreatojejunostomy: a prospective randomized study. Ann Surg. 2008;248(6):930-8. https://doi. org/10.1097/SLA.0b013e31818fefc7.

15. Figueras J, Sabater L, Planellas P, Muñoz-Forner E, Lopez-Ben S, Falgueras L, et al. Randomized clinical trial of pancreaticogastrostomy versus pancreaticojejunostomy on the rate and severity of pancreatic fistula after pancreaticoduodenectomy. Br J Surg. 2013;100(12):1597-605. https://doi. org/10.1002/bjs.9252

16. Grendar J, Ouellet JF, Sutherland FR, Bathe OF, Ball CG, Dixon E. In search of the best reconstructive technique after pancreaticoduodenectomy: pancreaticojejunostomy versus pancreaticogastrostomy. Can J Surg. 2015; 58(3):154-9. https://doi.org/10.1503/cjs.010014.

17. Topal B, Fieuws S, Aerts R, Weerts J, Feryn T, Roeyen G, et al. Pancreaticojejunostomy versus pancreaticogastrostomy reconstruction after pancreaticoduodenectomy for pancreatic or periampullary tumours: a multicentre randomised trial. The Lancet Oncology. 2013;14(7):655-62. https://doi.org/10.1016/S1470-2045(13)70126-8.

18. Wellner UF, Sick O, Olschewski M, Adam U, Hopt UT, Keck T. Randomized controlled single-center trial comparing pancreatogastrostomy versus pancreaticojejunostomy after partial pancreatoduodenectomy. Journal of Gastrointestinal Surgery. 2012;16(9):1686-95. https://doi.org/10.1007/s11605012-1940-4

19. Yeo CJ, Cameron JL, Maher MM, Sauter PK, Zahurak ML, Talamini MA, et al. A prospective randomized trial of pancreaticogastrostomy versus pancreaticojejunostomy after pancreaticoduodenectomy. Annals of Surgery. 1995;222(4):580-92. https://doi.org/10.1097/00000658-199510000-00014.

20. Butturini G, Daskalaki D, Molinari E, Scopelliti F, Casarotto A, Bassi C. Pancreatic fistula: definition and current problems. J Hepatobiliary Pancreat Surg. 2008;15(3):247-51. https://doi.org/10.1007/s00534-007-1301-y.

21. Bassi C, Dervenis C, Butturini G, Fingerhut A, Yeo C, Izbicki J, et al. Postoperative pancreatic fistula: an international study group (ISGPF) definition. Surgery. 2005;138(1):8-13. https://doi.org/10.1016/j.surg.2005.05 001.

22. di Mola FF, Tavano F, Rago RR, De Bonis A, Valvano MR, Andriulli A, et al. Influence of preoperative biliary drainage on surgical outcome after pancreaticoduodenectomy: single centre experience. Langenbecks Arch Surg. 2014;399(5):649-57. https://doi.org/10.1007/s00423-014-1184-8.

23. Ramacciato G, Mercantini P, Petrucciani N, Nigri GR, Kazemi A, Muroni M, et al. Risk factors of pancreatic fistula after pancreaticoduodenectomy: a collective review. Am Surg. 2011;77(3):257-69. https://doi.org/10.1177/ 000313481107700310

24. Machado NO. Pancreatic fistula after pancreatectomy: definitions, risk factors, preventive measures, and management-review. Int J Surg Oncol. 2012;2012:602478

25. Nakano Y, Hirata Y, Shimogawara T, Yamada T, Mihara K, Nishiyama R, et al. Frailty is a useful predictive marker of postoperative complications after pancreaticoduodenectomy. World journal of surgical oncology. 2020;18(1): 194. https://doi.org/10.1186/s12957-020-01969-7.

26. Herrera-Cabezon FJ, Sanchez-Acedo P, Zazpe-Ripa C, Tarifa-Castilla A, LeraTricas JM. Quality standards in 480 pancreatic resections: a prospective observational study. Revista espanola de enfermedades digestivas. 2015; 107(3):143-51.

27. Pan J, Ge X, Zhou W, Zhong X, Gu L, Zhu H, et al. Comparison of clinical outcomes between mesh-reinforced pancreatojejunostomy and pancreatogastrostomy following pancreaticoduodenectomy: a cohort study 11 Medical and Health Sciences 1103 Clinical Sciences. World J Surg Oncol 2018; 16(1).

28. Wang $X$, Xin Y, Pan J, Zhang N, Zhou W. A new feasible technique of meshreinforced pancreatojejunostomy and pancreatogastrostomy: retrospective analysis of 61 cases. World J Surg Oncol. 2012;10:114.

29. He T, Zhao Y, Chen Q, Wang X, Lin H, Han W. Pancreaticojejunostomy versus pancreaticogastrostomy after pancreaticoduodenectomy: a systematic review and meta-analysis. Digestive surgery. 2013;30(1):56-69. https://doi.org/10.1159/000350901.

30. Wente MN, Shrikhande SV, Muller MW, Diener MK, Seiler CM, Friess H, et al. Pancreaticojejunostomy versus pancreaticogastrostomy: systematic review and meta-analysis. Am J Surg. 2007;193(2):171-83. https://doi.org/10.1016/j.a mjsurg.2006.10.010.

31. Jin $Y$, Feng $Y Y, Q i X G$, Hao G, Yu YQ, Li JT, et al. Pancreatogastrostomy vs pancreatojejunostomy after pancreaticoduodenectomy: an updated metaanalysis of RCTs and our experience. World J Gastrointest Surg. 2019;11(7): 322-32. https://doi.org/10.4240/wjgs.v11.i7.322.

32. Gaujoux S, Cortes A, Couvelard A, Noullet S, Clavel L, Rebours V, et al. Fatty pancreas and increased body mass index are risk factors of pancreatic fistula after pancreaticoduodenectomy. Surgery. 2010;148(1):15-23. https:// doi.org/10.1016/j.surg.2009.12.005.

33. Kawaida $H$, Kono H, Amemiya $H$, Hosomura $N$, Watanabe $M$, Saito $R$, et al. Anastomosis technique for pancreatojejunostomy and early removal of drainage tubes may reduce postoperative pancreatic fistula. World journal of surgical oncology. 2020;18(1):295. https://doi.org/10.1186/s12957-020-02 067-4. 
34. Bassi C, Butturini G, Molinari E, Mascetta G, Salvia R, Falconi M, et al. Pancreatic fistula rate after pancreatic resection. The importance of definitions. Dig Surg. 2004;21(1):54-9. https://doi.org/10.1159/000075943.

35. Warshaw A, Torchiana D. Delayed gastric emptying after pylorus-preserving pancreaticoduodenectomy. Surg Gynecol Obstet. 1985;160(1):1-4.

36. Yeo CJ, Barry MK, Sauter PK, Sostre S, Lillemoe KD, Pitt HA, et al. Erythromycin accelerates gastric emptying after pancreaticoduodenectomy. A prospective, randomized, placebo-controlled trial. Ann Surg. 1993;218(3): 229-37; discussion 237-228. https://doi.org/10.1097/00000658-19930900000002.

37. Kurosaki I, Hatakeyama K. Clinical and surgical factors influencing delayed gastric emptying after pyloric-preserving pancreaticoduodenectomy. Hepato-gastroenterology. 2005;52(61):143-8.

38. Riediger H, Makowiec F, Schareck WD, Hopt UT, Adam U. Delayed gastric emptying after pylorus-preserving pancreatoduodenectomy is strongly related to other postoperative complications. J Gastrointest Surg. 2003;7(6): 758-65. https://doi.org/10.1016/S1091-255X(03)00109-4.

39. Park Y-C, Kim S-W, Jang J-Y, Ahn YJ, Park Y-H. Factors influencing delayed gastric emptying after pylorus-preserving pancreatoduodenectomy. Journal of the American College of Surgeons. 2003;196(6):859-65. https://doi.org/1 0.1016/S1072-7515(03)00127-3.

40. Yang C, Wu HS, Chen XL, Wang CY, Gou SM, Xiao J, et al. Pylorus-preserving versus pylorus-resecting pancreaticoduodenectomy for periampullary and pancreatic carcinoma: a meta-analysis. PloS one. 2014;9(3):e90316. https:// doi.org/10.1371/journal.pone.0090316.

41. Srinarmwong C, Luechakiettisak P, Prasitvilai W. Standard Whipple's operation versus pylorus preserving pancreaticoduodenectomy: a randomized controlled trial study. J Med Assoc Thailand. 2008;91(5):693-8.

42. Watanabe M, Usui S, Kajiwara H, Nakamura M, Sumiyama Y, Takada T, et al. Current pancreatogastrointestinal anastomotic methods: results of a Japanese survey of 3109 patients. Journal of Hepato-Biliary-Pancreatic Surgery. 2004;11(1):25-33. https://doi.org/10.1007/s00534-003-0863-6.

43. Wente MN, Veit JA, Bassi C, Dervenis C, Fingerhut A, Gouma DJ, et al. Postpancreatectomy hemorrhage (PPH): an International Study Group of Pancreatic Surgery (ISGPS) definition. Surgery. 2007;142(1):20-5. https://doi. org/10.1016/j.surg.2007.02.001.

44. Ryska M, Rudis J. Pancreatic fistula and postoperative pancreatitis after pancreatoduodenectomy for pancreatic cancer. Hepatobiliary surgery and nutrition. 2014;3(5):268-75. https://doi.org/10.3978/j.issn.2304-3881.2014.09. 05.

45. Schmidt U, Simunec D, Piso P, Klempnauer J, Schlitt HJ. Quality of life and functional long-term outcome after partial pancreatoduodenectomy: pancreatogastrostomy versus pancreatojejunostomy. Ann Surg Oncol. 2005; 12(6):467-72. https://doi.org/10.1245/ASO.2005.04.005.

46. Rault A, SaCunha A, Klopfenstein D, Larroude D, Epoy FN, Collet D, et al. Pancreaticojejunal anastomosis is preferable to pancreaticogastrostomy after pancreaticoduodenectomy for longterm outcomes of pancreatic exocrine function. J Am Coll Surg. 2005;201(2):239-44. https://doi.org/10.1016/j.ja mcollsurg.2005.03.026.

47. Hirono S, Murakami Y, Tani M, Kawai M, Okada K, Uemura K, et al. Identification of risk factors for pancreatic exocrine insufficiency after pancreaticoduodenectomy using a 13C-labeled mixed triglyceride breath test. World J Surg. 2015;39(2):516-25. https://doi.org/10.1007/s00268-014-2 832-4.

48. Wang D, Liu X, Wu H, Liu K, Zhou X, Liu J, et al. Clinical evaluation of modified invaginated pancreaticojejunostomy for pancreaticoduodenectomy. World journal of surgical oncology. 2020;18(1): 75. https://doi.org/10.1186/s12957-020-01851-6.

49. Wu T, Guo Y, Bi J, Liu S, Guo Y, Bao S. Modified duct-to-mucosa versus conventional pancreaticoenterostomy for pancreaticoduodenectomy: a retrospective cohort study based on propensity score matching analysis. World journal of surgical oncology. 2019;17(1):5. https://doi.org/10.1186/s12 957-018-1557-5.

\section{Publisher's Note}

Springer Nature remains neutral with regard to jurisdictional claims in published maps and institutional affiliations.

\section{Ready to submit your research? Choose BMC and benefit from}

- fast, convenient online submission

- thorough peer review by experienced researchers in your field

- rapid publication on acceptance

- support for research data, including large and complex data types

- gold Open Access which fosters wider collaboration and increased citations

- maximum visibility for your research: over $100 \mathrm{M}$ website views per year

At BMC, research is always in progress.

Learn more biomedcentral.com/submissions 